\title{
Ancestral Caddo Ceramic Artifacts in the Jesse Martin Glasco Collection from Upshur County, Texas, at the National Museum of Natural History, Smithsonian Institution
}

Timothy K. Perttula

Heritage Research Center, Stephen F. Austin State University

Follow this and additional works at: https://scholarworks.sfasu.edu/ita

Part of the American Material Culture Commons, Archaeological Anthropology Commons, Environmental Studies Commons, Other American Studies Commons, Other Arts and Humanities Commons, Other History of Art, Architecture, and Archaeology Commons, and the United States History Commons

Tell us how this article helped you.

This Article is brought to you for free and open access by the Center for Regional Heritage Research at SFA ScholarWorks. It has been accepted for inclusion in Index of Texas Archaeology: Open Access Gray Literature from the Lone Star State by an authorized editor of SFA ScholarWorks. For more information, please contact cdsscholarworks@sfasu.edu. 


\section{Ancestral Caddo Ceramic Artifacts in the Jesse Martin Glasco Collection from Upshur County, Texas, at the National Museum of Natural History, Smithsonian Institution}

Creative Commons License

(c) (1) \& 8

This work is licensed under a Creative Commons Attribution-NonCommercial 4.0 International License 


\title{
Ancestral Caddo Ceramic Artifacts in the Jesse Martin Glasco Collection from Upshur County, Texas, at the National Museum of Natural History, Smithsonian Institution
}

\author{
Timothy K. Perttula
}

\begin{abstract}
Introduction
Jesse Martin Glasco, or J. M. Glasco, lived in Gilmer in Upshur County, Texas, between the mid1840s and 1886. During most of those years he served as Upshur County surveyor and deputy surveyor, as well as deputy county clerk, postmaster, and tax assessor, and he also represented Upshur County in the $11^{\text {th }}$ Texas legislature. Between 1859-1861 and 1867-1873, he was a meteorological observer for Upshur County for the Smithsonian Institution, and also collected Native American pottery for the Smithsonian's collections from the Gilmer area (Hawkins and Hicks 2010).
\end{abstract}

\section{Ancestral Caddo Ceramic Artifacts}

The ancestral Caddo ceramic artifacts collected by Glasco and donated to the National Museum of Natural History, Smithsonian Institution (NMNH), were documented in 2005 during a repatriation consultation visit. The artifacts include a Taylor Engraved bottle (Figure 1) and 13 decorated vessel sherds. The bottle and the decorated sherds are from a Late Caddo period Titus phase component at a site that was probably occupied after ca. A.D. 1550.

Among the decorated sherds are three Bailey Engraved bottle sherds with engraved and engravedpunctated decorative elements (Figure 2; see Suhm and Jelks 1962:Plate 3). Another sherd in the collection (Figure 3, lower left) may be from a separate engraved-punctated Bailey Engraved bottle. Other sherds in the collection include utility wares with punctated and incised rim and body sherds (Figure 3, top right and lower right and Figure 4, lower right) and Bullard Brushed body sherds (Figure 4, lower left and center). The horizontal incised rim sherd also has short diagonal incised lines beneath the lip, and is lip notched (Figure 3, top right).

Four of the decorated rim sherds collected by Glasco are from Ripley Engraved vessels. One rim is from a Ripley Engraved, var. McKinney vessel with a central circle element and an inner diamond element (see Figure 3, top left), and another is from a Ripley

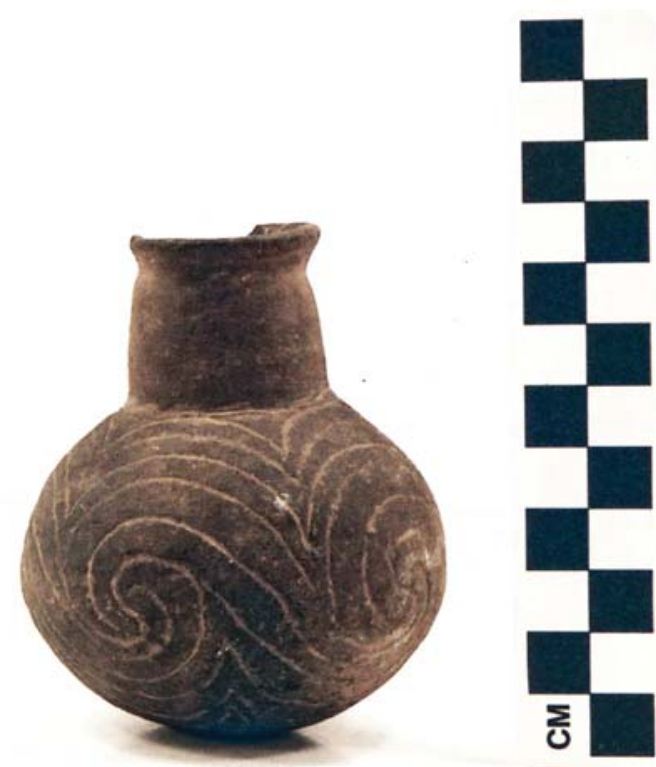

Figure 1. Taylor Engraved bottle. Catalog \#A010102, NMNH.

Engraved, var. Pilgrims vessel with part of an interlock-

ing horizontal scroll motif. A third rim has an excised bracket element (see Figure 4, top center), and the last Ripley Engraved rim has portions of an open engraved bracket element (see Figure 4, top right). 


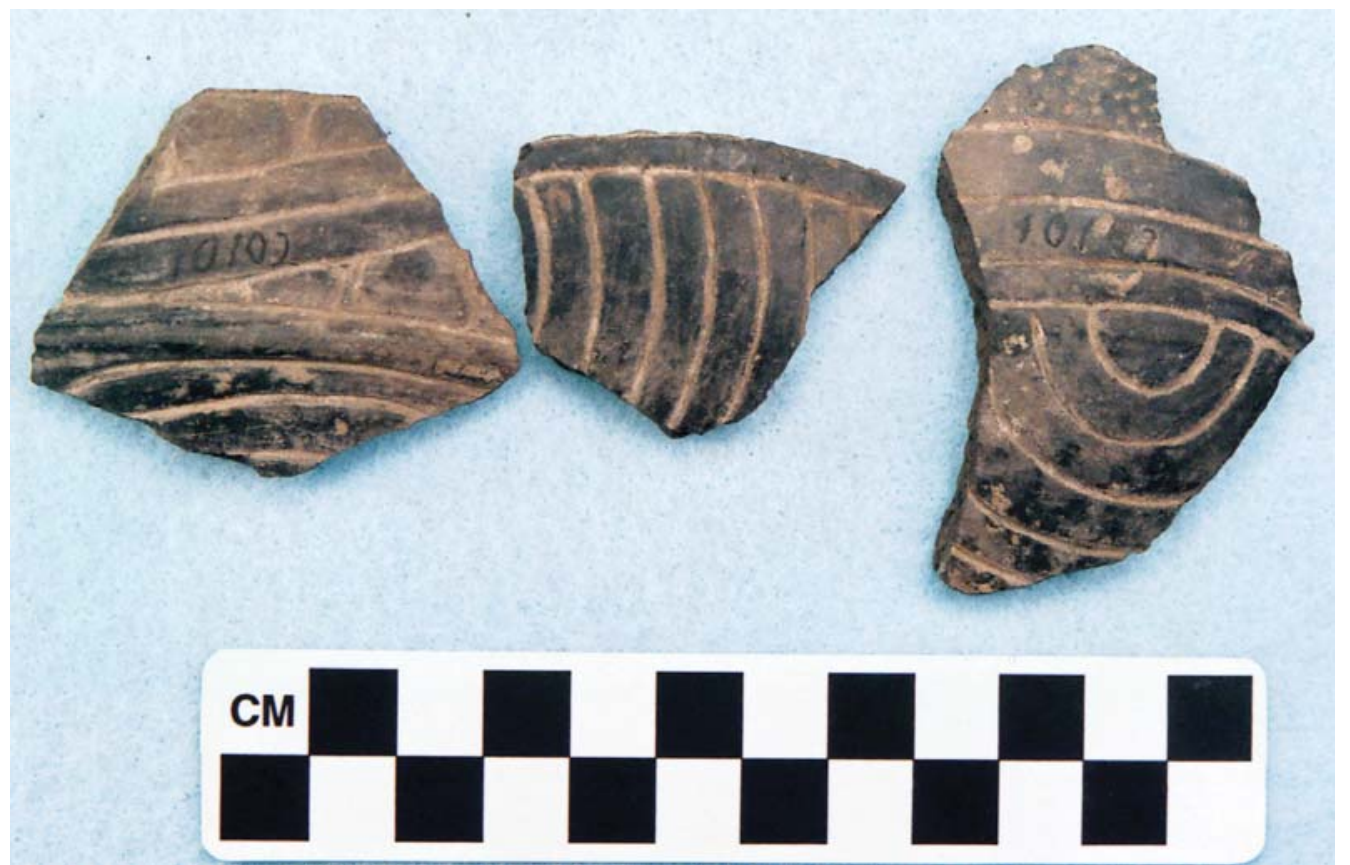

Figure 2. Bailey Engraved bottle sherds. Catalog \#A010102, NMNH.

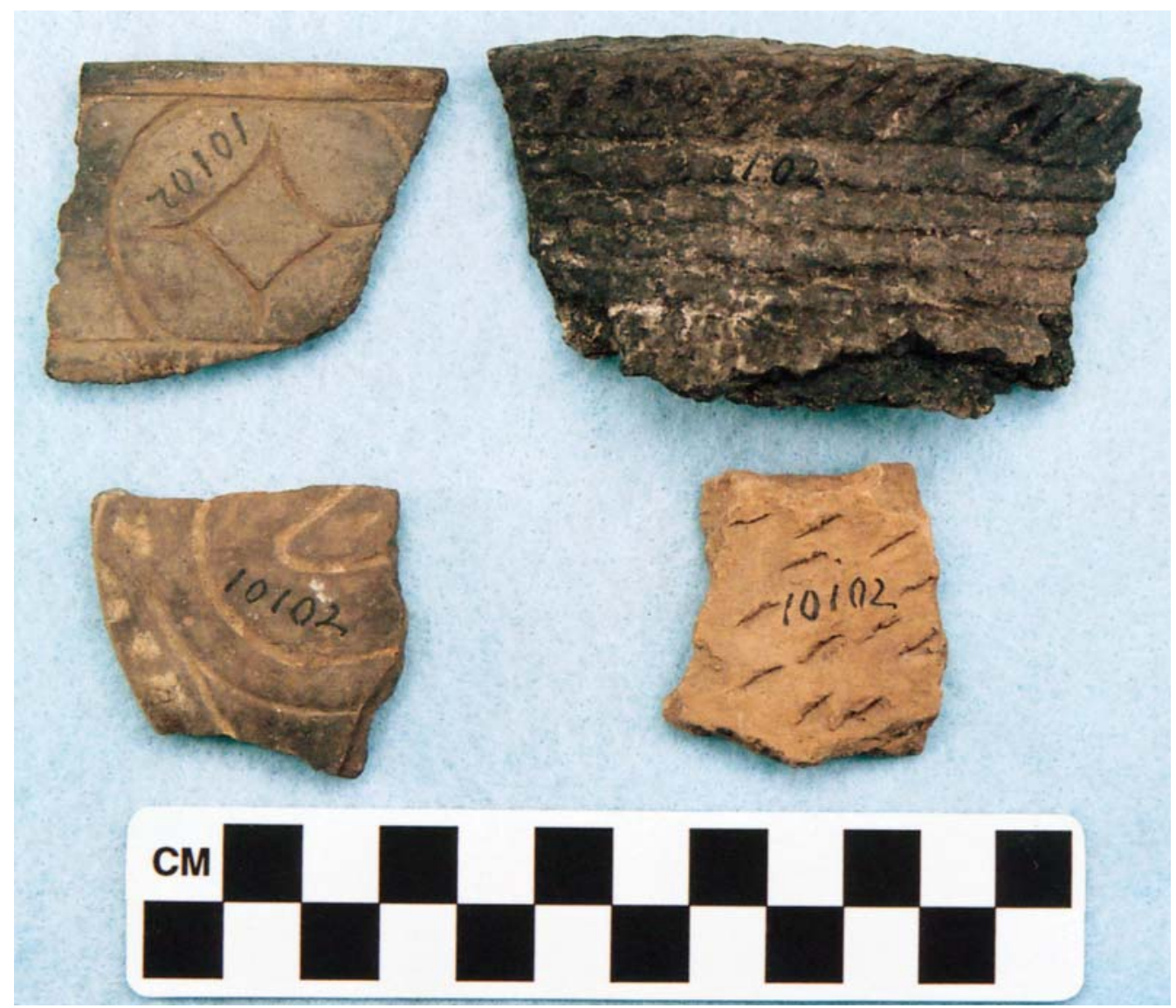

Figure 3. Other fine ware and utility ware sherds collected by J. M. Glasco. Catalog \#A010102, NMNH. 


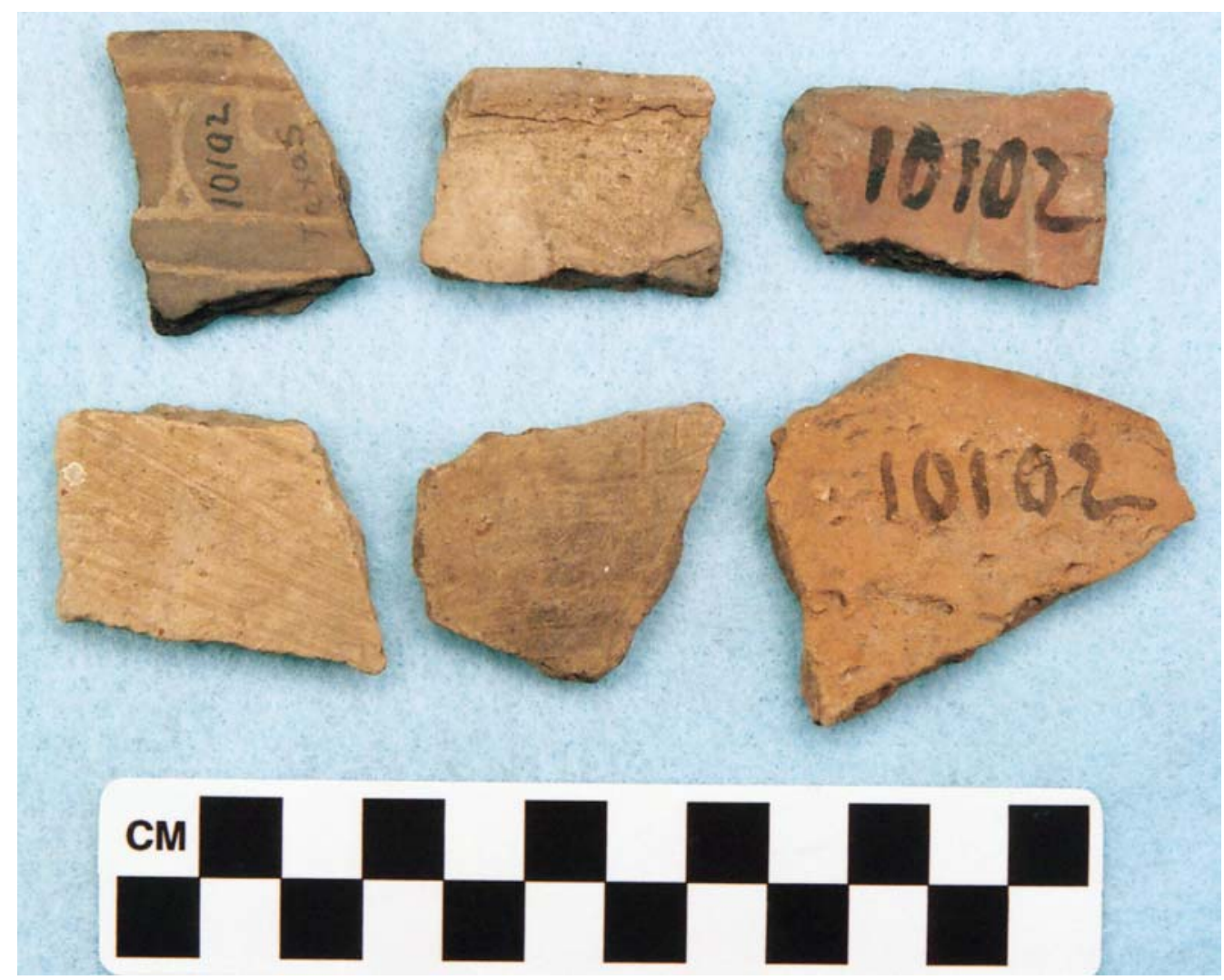

Figure 4. Engraved and utility ware sherds in the Glasco Collection at NMNH. Catalog \#A010102.

\section{Summary and Conclusions}

A single ceramic bottle and ceramic sherds from at least 10 different vessels from an ancestral Caddo site in the Gilmer area of Upshur County in East Texas were collected by Jesse Martin Glasco sometime in the late $19^{\text {th }}$ century and donated to the Smithsonian Institution. These sherds are from Bailey Engraved, Ripley Engraved, and Taylor Engraved fine ware vessels and Bullard Brushed utility wares; other utility ware vessels have either incised or punctated decorative elements. The types of ceramic artifacts are indicative of a Titus phase occupation, and such occupations are common in the Gilmer area (see Parsons 1998, 2015). The Taylor Engraved bottle and the Ripley Engraved, var. McKinney rim sherd further suggest that the Caddo site likely dates after ca. A.D. 1550, during the late Titus phase.

\section{Acknowledgments}

Bo Nelson took the photographs used in this article.

\section{References Cited}

Hawkins, M. G. and T. J. Hicks

2010 Glasco, Jesse Martin. Handbook of Texas Online (http://www.rshaonline.org/handbook/online/articles/ fg103, accessed November 9, 2015). Published by the Texas State Historical Association. 
Parsons, M. L.

1998 41UR133: A Late Caddo Hamlet at Lake Gilmer. Cultural Resource Management News \& Views 10(1):1619. Division of Antiquities Protection, Texas Historical Commission, Austin.

2015 Archeological Investigations at Lake Gilmer, Upshur County, Texas Mitigation Phase. Archeology Reports Series, No. 6. Texas Historical Commission, Austin.

Suhm, D. A. and E. B. Jelks (editors)

1962 Handbook of Texas Archeology: Type Descriptions. Special Publication No. 1, Texas Archeological Society, and Bulletin No. 4, Texas Memorial Museum, Austin. Reprinted in 2009, Gustav's Library, Davenport, Iowa. 